\title{
PENSIONERS' QUALITY OF LIFE IN MODERN UKRAINE: SOCIO-ECONOMIC AND VALUE-REGULATORY ASPECTS
}

\author{
Alla LOBANOVA ${ }^{1 *}$, Liudmyla BRATCHENKO ${ }^{2}$, Olena KOMAROVA ${ }^{3}$ \\ ${ }^{1}$ Silesian University of Technology, Faculty of Organization and Management, Department of Applied Social \\ Sciences, Zabrze, Poland; alla.lobanova@polsl.pl, ORCID: 0000-0003-3852-2675 \\ ${ }^{2}$ Kryvyi Rih State Pedagogical University, Department of Sociology and Economics, Kryvyi Rih, Ukraine; \\ ludmilabratchenco@gmail.com, ORCID: 0000-0002-1798-5251 \\ ${ }^{3}$ Kryvyi Rih State Pedagogical University, Department of Sociology and Economics, Kryvyi Rih, Ukraine; \\ komarovaalena@i.ua, ORCID: 0000-0002-1054-0268 \\ * Correspondence author
}

Purpose: Is to clarify the content of the category "quality of life", identify its indicators, as well as to explain the level of quality of life of population, including Ukrainian pensioners and the state of the pension system as its basic financial basis, and also to determine social and economic, value and normative factors that form the quality of life of the elderly people.

Design/methodology/approach: The paper uses theoretical methods: analysis and synthesis, formalization, hypothetical-deductive, systematization and generalization, as well as empirical: observation, description, comparison.

Findings: The content of the category "quality of life" is specified; the Ukrainian method of determining indicators of quality of life is presented. The socio-economic condition and quality of life of Ukrainians, in particular pensioners, as well as the state of the pension system as a basic factor that forms the basis of their life opportunities are analyzed. Insufficient efficiency of the pension system in Ukraine, absence of effectiveness of private pension funds are substantiated, which limits the ability of retirees to implement such vital values as proper recreation, medical services, cultural and educational development, travel, assistance and support of children and grandchildren. Ways to improve the pension system in Ukraine, including the second (mandatory funded system) and third levels (voluntary private pension provision) are proposed.

Research limitations/implications: Perspective areas of further research are the search for ways to implement the elements of the best standards of pension systems of foreign countries, in particular Poland, in the pension system of Ukraine.

Practical implications: The results of the research can be used by state institutions to improve the pension system in Ukraine, and thus bring the lives of Ukrainian pensioners closer to European standards.

Social implications: The results of the research are of great social importance, as they identify trends in improving the lives of the most vulnerable people in Ukraine - pensioners, most of whom live below the poverty line.

Originality/value: The originality of research paper is to determine the socio-economic and value-normative factors that form the quality of life of modern Ukrainian pensioners; in particular, it has been proved that the pension system in Ukraine is imperfect, does not meet 
European standards, as a result of which almost $60 \%$ of pensioners live below the poverty line, as they cannot provide the minimum material and socio-cultural needs; ways to improve pension provision in Ukraine are outlined.

Keywords: pensioners, quality of life, pension system, life values, social and economic needs.

Category of the paper: Research paper.

\section{Introduction}

The economy of modern Ukraine is experiencing a difficult period of crisis. This is due to a number of both internal and external factors. Internal problem areas include the following: the six-year military conflict in the east of the country (since March, 2014) with the assistance of the Russian Federation, the existence of the hidden economy and informal employment practices, the instability of the financial and banking system, labor migration of able-bodied citizens to European countries, an ineffective system of state social insurance and others. External factors include the global economic crisis and the global COVID-19 pandemic, which strict quarantine measures have significantly complicated the activities of business structures. These internal and external factors lead to the fact that incomes of taxes to the state budget from the activities of the hidden economy and informal employment practices are not fully realized. Thus the revenues to public consumption funds are reduced. At the same time, significant financial flows are aimed at overcoming the effects of the COVID -19 pandemic.

According to the first results of the hidden economy of Ukraine research, which was conducted by Ernst \& Young with the support of MasterCard in the framework of the Memorandum of Cooperation with the Ministry of Economy, Trade and Agriculture of Ukraine, the National Bank of Ukraine and the State Statistics Service of Ukraine at the beginning of 2020, hidden transactions amount to 846 billion UAH (about 32 billion dollars). This is a quarter of Ukraine's official GDP (about 125 billion USD) (Doslidzhennia tinovoi ekonomiky, 17.02. 2020).

Certainly, in an underdeveloped economy, the state budget, in particular its public consumption funds, cannot fully meet the real needs of those social groups that demand state social support. Ukrainian pensioners are particularly vulnerable, and their quality of life requires to be improved significantly.

The social question at issue is the pensioners' quality of life, and also the state and nature of their social support in Ukraine need to be improved, and the pension insurance system also needs immediate improvement and/or reforming.

Thus, the aim of this article is to clarify the content of the category "quality of life", identify its indicators, as well as to explain the level of quality of life of population, including Ukrainian pensioners and the state of the pension system as its basic financial basis, and also to determine 
social and economic, value and normative factors that form the quality of life of the elderly people.

\section{Methods}

The writing of the research paper was based on the use of such general scientific methods as analysis and synthesis, deduction and induction, abstraction and concretization, formalization and comparison, systematization and generalization. Sociological, psychological, economic and legal, as well as systemic, structural-functional, statistical, value-normative were the main approaches to solving research problems. Empirical methods used in the study were observation, description, comparison, methods of socio-economic statistics.

Analytical processing of the scientific literature made it possible to clarify scientific approaches to understanding the concept of "quality of life", and the method of systematization and generalization - to specify its content and internal interdependencies. The sociological approach revealed the social aspects of pensioners' lives, the economic one - the level of their material security, the legal - the guarantee of pension provision, the psychological - the state of satisfaction of pensioners with the level and quality of their lives.

The state, structure and problems of the pension system that functions in Ukraine have been identified with the help of systematization and structural-functional method. Value-normative method helped to find out the level of satisfaction of Ukrainian pensioners with their standard of living and moral and psychological state. The use of statistical analysis allowed to identify indicators of quality of life of pensioners and compare them with the standard of living in European countries. Empirical methods such as observation, description and comparison were used to clarify theoretical conclusions and positions and helped to find answers to the purpose and tasks of the research paper.

\section{Results}

Quality of life is one of the most popular issues in almost all sciences: social, economic, law and others. Meanwhile, there is still no common scientific definition of this notion. Although the intentions to understand the phenomenon it describes were inherent to social scholars of all historical epochs experienced by mankind.

Probably, this is due to the extraordinary importance of this phenomenon for people's lives, as the ultimate goal of each state is to improve the level and quality of life of the population. It is worth paying attention to the multifaceted nature of the social phenomenon it describes. 
Therefore, there are different scientific approaches to understand the quality of life. According to I. Romaniuk, there are at least three scientific approaches in the process of defining this concept:

- objective approach (R. Bayer, A. Biederman, B. Gross, F. Forrester, M. Morris, D. Johnston and others), which determines the quality of life through a set of statistical indicators that are summarized to one index;

- subjective approach (subjective well-being), which studies the quality of life through the prism of the subject's consciousness, his satisfaction of life and private aspects, as well as through feelings of happiness or unhappiness (M. Bradburn, S. McCall, K. Terhune, A. Mitchel, Th. Logoletti, R. Kantor, Ph.E. Converse, W. Rodgers, A. Campbell, M. Abrami, F.M. Andrews, S.B. Whitty);

- economic approach, whose supporters (R. Aron, T. Attali, D. Bell, J. Galbraith, M. Guillaume, D. Meadows, W. Rostow, A. Touraine, J. Forrester) consider quality of life as a necessary attribute of the new post-industrial society and link this indicator with the achievement of a certain level of material well-being, economic development and try to measure it through a system of objective indicators, including factors such as living standards, income levels, demographic rates, environmental pollution and others (Romaniuk, 2014).

The World Health Organization (WHO) defines quality of life as "a person's perception of his or her life position in the cultural context and the value system in which he or she lives and with the help of which he or she is guided by in accordance with tasks, expectations and environmental standards (WHOQOL Group, 1995). In other words, the emphasis is on the subjective assessment of the state of life and its assessment, which, by the way, depends entirely on external circumstances.

At the same time, it is expedient to describe the quality of life also through value and normative, structural, historical, comparative, psychological and other approaches. After all, it lays a wide range of vital planes of human life and activity. Therefore, it can be analyzed both from the individual's point of view and from the point of view of the external circumstances in which he lives: law, economic, social, cultural, geographical, climatic and other conditions. A broad context of the quality of life in relation to the concept of sustainable development is presented by A. Kuzior (Kuzior, 2006; 2008, 2013; 2014).

I. Hukalova points out that the complexity of this category led to the intention of representatives of different sciences to structure the concept in their own way and select for its evaluation the most interesting indicators in terms of specific science (Hukalova, 2009, p. 26).

For instance, the Ukrainian researcher A. Kolot believes that the quality of life is "the level of human needs satisfaction, which is determined in relation to the relevant norms, social standards, traditions, customs or in accordance with the established personal requirements" (Kolot, 2003, p. 74). Russian economist V. Adamchuk considers the standard of living as "the structure of the material needs of the population and the degree of their satisfaction; 
integral indicator that characterizes the consumption of material and mental goods by the population and the needs satisfaction degree for these goods at a certain historical moment of social production (Adamchuk, 1999).

In the conditions of technogenic nature and climate changes load, quality of life more and more often began to be considered through a prism of a physical condition of the person. It is no coincidence that Polish researchers B. Szyguła-Jurkiewicz, M. Kowalska, M. Mościński, emphasize that in recent years more and more often there is a tendency in clinical studies and in everyday medical practice that the quality of life of the patient depends on his state of health, in the sense of the impact of the disease and its treatment on its functioning in the physical, mental and social spheres (Szyguła-Jurkiewicz et al., 15.06.2020).

I. Romaniuk defines the quality of life as a complex subject and object characteristic of living conditions of an individual and society as a whole and believes that the individual's perception of the category "quality of life" is due to the interrelated influence of four main psychological factors: motivation, perception, attitudes and beliefs (Romaniuk, 2014, pp. 95-96).

Meanwhile, the discussion on the content and structure of the category "quality of life" is not over. As a subject of sociological research, the quality of life of the population is considered by scientists because its indicators are not only statistical, but also self-assessment and assessment of the population of their lives, which is possible only during sociological research.

The world's best-known integrated indicator of quality of life is the Human Development Index (HDI), which can be used to assess and compare poverty, literacy, education, product life expectancy and other indicators in different countries. The index was developed in 1990 by Pakistani economist Mahbub ul Haq and has been used by the United Nations since 1993 in its annual report on human development. Three types of indicators are taken into account while calculating the HDI: product life expectancy at birth - estimates longevity; education index: literacy level of the adult population of the country (2/3 of the index) and the total percentage of pupils and students (1/3 of the index); standard of living, estimated in terms of GDP per capita at purchasing power parity (PPS) in USD. The Poverty Index is an alternative index (also developed by the United Nations to assess the quality of life in any country) (Romaniuk, 2014, pp. 95-96).

Thus, quality of life as a scientific category describes a multifaceted and quite complex for research and assessment social, economic, law, cultural and psychological phenomenon, which is inherent in each individual and community, society as a whole, as it characterizes the level of living standards implementation (economic, law, social, environmental, cultural, medical, psychological and others), their degree of satisfaction with social and economic conditions created in the state to satisfy diverse requirements (economic, educational, material, psychological, social, cultural, sports, permits, etc.) and social support and protection by government agencies and institutions in terms of health loss or disability. 
In Ukraine, scientists from the Ptoukha Institute for Demography and Social Studies of the National Academy of Sciences of Ukraine developed a system of indicators for assessing the quality of life of the Ukrainian population for comprehensive monitoring, including comparison with other countries, based on the national matrix. It includes the following three blocks of indicators:

- quantitative indicators of the external environment in which human life and the assessment of quality of life take place;

- characteristics of the current state of quality of life, which is formed as a result of the joint influence of the state and the population;

- subjective assessment of the quality of life of each individual (social strata, groups) in terms of their perception of the availability of different resources and the possibility of their use (Libanova et al., 2013).

On the basis of this matrix it is possible to make a configuration of those subsystems of life which are subject to an assessment when it is a question of measurement of quality of life:

- economic, natural, social, political environment as social spheres of society that provide living conditions for the individual;

- social, labor, family, personal life - subsystems that determine the subjective standard of living and meeting the individual needs.

According to the results of the Numbeo service research, in the quality of life ranking over 2018 (latest data) Ukraine was ranked 62nd among 71 countries on the list. A step higher in the ranking was Thailand, below was Hong Kong. In all 3 countries, the quality of life index barely exceeds 100 (in Ukraine, for example, 102.34). On the other hand, the leader of the Danish list has a score twice as high - 198.57. The researchers separately assessed countries' purchasing power, security, health care, cost of living, real estate affordability, transportation, pollution and the environment. There is the worst situation in Ukraine with purchasing power (32.72 points), cost of living (27.94) and transport (14.35) (Chomu v Ukraini nyzkyi riven yakosti zhyttia, 16.06.2020). Commenting on this situation, economist L. Cherenko noted that Ukraine has such a low rate due to the following reasons: the war reduces the country's security, as well as significant impact of the hryvnia's collapse in 2014-2015. According to the other indicators, everything is stable: "Since 2017, the situation with purchasing power has begun to improve, although the ranking has different data for the above reasons. The same situation happened with transport. The low score may be due to comparative characteristics with other countries. This is not the first problem for us. People are more concerned about the availability of health services, purchasing power and other social issues"(Chomu v Ukraini nyzkyi riven yakosti zhyttia, 16.06.2020).

Describing Ukrainians' state and quality of life, Director of Ptoukha Institute for Demography and Social Studies of the National Academy of Sciences of Ukraine, Academician E. Libanova noted that Ukraine's independence, formation of new international contacts, joining the new globalized world caused a deep economic crisis of transition, which found 
glaring inequality in society, that may even lead to its division into castes. Moreover, in the last few years, a completely new concept of "sudden poverty" has emerged in Ukraine. Reasons of its appearing were as follows: the annexation of Crimea, the fighting in the east, and almost 2 million forced migrants (Iakist zhyttia v Ukraini, 4.07.2020). Surely, the state and quality of life of Ukrainians at the beginning of 2020 were affected not only by these phenomena, but also by the global COVID-19 pandemic, which forced the government to apply strict quarantine measures, that deprived many people of jobs and stable earnings. The difficult environmental situation also has a negative impact on people's well-being and health.

The consequence of all these challenges is the extremely low life expectancy of Ukrainians compared to residents of other countries. Thus, the average life expectancy in Ukraine of both sexes averages 71.1 years now. This is lower than the world average index, which is 71.7 . In the Czech Republic it is 78.8, in Poland - 77.6, in Hungary - 75.3. The average life expectancy of women in Ukraine is 76 years, of men is 66.2 years. In the Czech Republic, women live on average 81.6 years, men -75.9 , in Slovakia women live 80 , and men 77.2 years, in Poland women live 5.5 years longer (81.5) than in Ukraine, and men for 7.5 years (73.5) (Iakist zhyttia v Ukraini, 4. 07. 2020). Ukraine has an extremely low level of national income per capita in USD (purchasing power). If in 1990 it reached \$10.8 thousand per person per year, now it has dropped to $\$ 7.4$ thousand. In the Czech Republic, it is $\$ 29.8$ thousand, in Slovakia - \$27.4, in Romania - \$19.9 thousand. Thus, United Nations experts stated that more than $60 \%$ of the population of Ukraine is below the poverty line now. In other words, they live on less than $\$ 8$ a day per person. It is no coincidence that the general index of Ukrainians' satisfaction of their own lives (it includes satisfaction of education $-50 \%$, health care $-22 \%$, standard of living $-17 \%$, work $-39 \%$, security $-44 \%$, freedom of choice $63.5 \%$ ) is much lower than in adjoining European countries and is 4.0. In Poland this index is 6.0, in the Czech Republic - 6.6 points, and satisfaction of public life (local labor market $-8 \%$, leisure opportunities $-16 \%$, local government $-76 \%$, law system $-4 \%$, environmental protection $-13 \%$, central government $-8 \%$ ) is 8 points, while in Poland this index amount to 21 points, and in the Czech Republic - 44 points (Iakist zhyttia v Ukraini, 4.07.2020).

Pensioners are a particularly vulnerable group of the population, which is acutely aware of changes in the quality of life level, as their state of life remains a major social problem in modern conditions.

At the beginning of 2020, the number of pensioners in Ukraine was 11.3 million people, and the average amount of pension payments was 3082.98 UAH or 130.19 USD (the dollar exchange rate on January 1, 2020 was 23.68) (Kurs NBU, 01 01.2020).

Ukrainian pensioners receive 4.5 times less pension, in comparison to Poland, where the average pension benefit in the first half of 2019 was 2,236.84 Zloty (Dani pro serednii rozmir pensii stanom, 29.06.2020; Ile wynosi średnia emerytura w Polsce, 29.06.2020). 
Extremely low level of pensions of Ukrainian pensioners becomes obvious with the comparison with pensioners of European countries, and thus impoverishment and inability to provide for their own needs without additional assistance from children become obvious too, if they do not exist (see Table 1).

Table 1.

The minimum old-age pension in Ukraine, compared to Poland in 2014-2021

\begin{tabular}{|c|c|c|c|c|c|c|c|c|c|}
\hline $\begin{array}{l}\text { Minimum } \\
\text { pension }\end{array}$ & 2014 & 2015 & 2016 & 2017 & 2018 & 2019 & 2020 & 2021 & $\begin{array}{l}\text { Changes in } \\
\text { pension in } \\
2021 \\
\text { compared } \\
\text { to } 2014 \\
\end{array}$ \\
\hline $\begin{array}{l}\text { Ukraine } \\
\text { Dollar/ } \\
\text { hryvnya }\end{array}$ & $\begin{array}{l}111.91 / \\
894.00\end{array}$ & $\begin{array}{l}60.22 / \\
949.00\end{array}$ & $\begin{array}{l}47.01 / \\
1130.00\end{array}$ & $\begin{array}{l}58.86 / \\
1247.00\end{array}$ & $\begin{array}{l}48.92 / \\
1373.00\end{array}$ & $\begin{array}{l}54.03 / \\
1497.00\end{array}$ & $\begin{array}{l}69.13 / \\
1638.00\end{array}$ & $\begin{array}{l}62.54 / \\
1769.00\end{array}$ & $\begin{array}{l}-49.46 \mathrm{USD} / \\
+875.00 \mathrm{UA}\end{array}$ \\
\hline $\begin{array}{l}\text { Poland } \\
\text { Dollar/ } \\
\text { zloty }\end{array}$ & $\begin{array}{l}266.39 / \\
831.15\end{array}$ & $\begin{array}{l}227.00 / \\
844,45\end{array}$ & $\begin{array}{l}216.32 / \\
880.45\end{array}$ & $\begin{array}{l}218.45 / \\
882.56\end{array}$ & $\begin{array}{l}293.25 / \\
1000.00\end{array}$ & $\begin{array}{l}273.88 / \\
1029,80\end{array}$ & $\begin{array}{l}282.77 / \\
1100.00\end{array}$ & $\begin{array}{l}323.45 / \\
1200,00\end{array}$ & $\begin{array}{l}+57.06 \mathrm{USD} / \\
+368.85 \mathrm{ZL}\end{array}$ \\
\hline
\end{tabular}

This table shows that the minimum level of pension in Ukraine from 2014 to 01.01.2021increased in hryvnya in 2 times (1769 UAH vs. $894 \mathrm{UAH}$ ), and in Poland in zlotys - 4.5 times (1200 zl vs. $266 \mathrm{zl}$ ). At the same time, the dollar equivalent in Ukraine decreased by 49.46 dollars, and in Poland - increased by 368.85 dollars. Moreover, as of January 1, 2021, the minimum pension of Polish pensioners is 5 times higher than that of Ukrainian pensioners (\$323.45 vs. \$62.54). (Minimum old-age pension, 2021; Minimum and maximum old-age pension, 2021; NBU exchange rate, 2021; Emerytura minimalna, 2021; Kursy walut, 2021).

Certainly, the low amount of the pension does not improve the living standards of pensioners, so they need a special state system of social support. One of the most important components of the system of social protection of the elderly people and improving the quality of their lives is pension insurance, which significantly affects social and economic status of retirees and their valuable and normative attitude to life.

\section{Discussions}

The current pension system of Ukraine was established on July 9, 2003, when the Verkhovna Rada (Supreme Council of Ukraine) passed two acts on pension reform: "On Compulsory State Pension Insurance" and "On Non-State Pension Provision" (Yatsenko, 29.06.2020). It is a set of law, economic and organizational institutions and norms, the purpose of which is to provide citizens with material support in the form of a pension. Regardless of the type of pension system, pensionary payments, as USAID Financial Sector Transformation Project Consultant V. Yatsenko noted, are "requirements for future output", as to live a decent 
life on a pension, elderly people "do not need paper money on their own or paper "accrued assets" (shares and bonds), but available goods (food, medicine, clothing) and services (medical, housing and communal services) produced by the working population" (Yatsenko, 29.06.2020). In other words, the pension level determines material, social and cultural standard of living of the elderly people. The lower the pension is, the less opportunities they have to meet their physiological, social and cultural needs.

The pension system of Ukraine has three levels: the first level is the solidarity system of compulsory state pension insurance; the second level - the accumulative system of compulsory state pension insurance; and the third level is private pension funds (PPFs) with voluntary contributions, which were established in 2005.

How effectively do these three levels of the pension system work? According to experts, only the first and the third levels of the pension system operate in Ukraine. However, the third level (voluntary non-state pension provision) is bare of credit of Ukrainian citizens. The second level of the pension system (the accumulative system of compulsory state pension insurance) would work from 2012 and provide for the deduction of up to $7 \%$ of the employee's salary to his personal account. And these funds were to "work", in other words, to invest into the Ukrainian economy, and the income from this investment in the future would increase the amount of pension benefits.

However, as practice shows, this level does not work at all. According to experts, in Ukraine private pension funds have assets of only $\$ 97$ million or $0.1 \%$ of GDP and cover only $5 \%$ of employees. Almost $40 \%$ of them are members of one professional non-state pension fund "Magistral" of "Ukrzaliznytsia" (Ukrainian Railways) employees, who have accumulated an average of UAH 115 (\$4.1). While, for example, in Denmark, which ranks first in the world in terms of the value of private pension assets, they will amount to $\$ 722$ billion, which is $208 \%$ of GDP (2017), the Netherlands - \$1.628 trillion (184\% to GDP). About $94 \%$ of employees in the Netherlands and $90 \%$ in Denmark cover about by private pension plans (Yatsenko, 29.06.2020).

Nowadays the issue of decent pension provision for Ukrainian citizens is extremely important. It requires the study of foreign experience of the world"s leading countries and urgent reform of the pension system.

It should be noted that most European countries have experienced or are experiencing similar problems in the pension system. The main reasons are: demographic problems that lead to a reduction in the labor force and an aging population, as well as economic ones. Ensuring social justice, economic and financial stability requires the introduction of a multi-level pension system, which has been successfully tested for many years in the world's leading countries.

The Melbourne Mercer Global Pension Index assesses the adequacy, sustainability and integrity of the pension systems of 34 countries using more than 40 indicators from zero to 100 points. It shows which countries are best and worst prepared for the aging population. According to V. Yatsenko, due to falling birth rates, which has led to a reduction in the number 
of children in almost half of the world, increasing life expectancy and reducing mortality, population aging is becoming one of the biggest challenges for governments around the world. There are more pensioners in Ukraine than their grandchildren. Over the past 60 years, the share of the population aged 60 and over has more than doubled - from $10 \%$ according to the 1959 census to $23 \%$ in 2018 according to the State Statistics Service. At the same time, the share of the population under 19 decreased from $34 \%$ to $20 \%$. The median age of the country's population has increased one and a half times for 60 years: from 27.6 years to 40.8 years (Yatsenko, 29.06.2020). The last census in Ukraine was conducted in 2001. Therefore, the exact number of able-bodied citizens who have to pay taxes is unknown. After all, in the field of informal employment (taxes are not paid) in the country, according to various estimates, about a third of able-bodied citizens work. The annexation of Crimea, the war in Donbass and largescale labor migration to the European Union, in particular Poland, also had a significant impact on the demographic situation of the population. Therefore, the Government of Ukraine is looking for ways to improve the pensions of its citizens.

A new stage of pension reform took place on October, 2017. Its main purpose is to equalize the expenditure and income parts of the Pension Fund of Ukraine (PFU). The reduction of the PFC deficit, which gradually took place from 2016 to 2018 (from 85.6 billion UAH to 32.1 billion $\mathrm{UAH}$ ), indicates that positive changes in pension provision have begun to take place (Defytsyt Pensyonnoho fonda, 26.06.20). However, this does not solve the general problem that exists in Ukraine regarding the standard of living and well-being of pensioners.

Today Ukraine urgently needs effective steps to reform the pension system not on paper, but in real life. We agree that the main changes in the reform are linked to length of service, not age; annual indexation and increase of the minimum pension.

Determination of old-age pension in Ukraine in 2019 is carried out in accordance with the Law of Ukraine "On Compulsory State Pension Insurance" and observing two conditions:

1) reaching retirement age,

2) availability of sufficient insurance experience.

The increase of the retirement age and amount of minimum insurance experience required for a pension occurred on October 1, 2011. In addition, a new pension reform was carried out. According to this pension reform there is a gradual increase in retirement age starting from January 1, 2018. The retirement age in Ukraine for both men and women is set at the same level - 60 years. However, women will retire at age 60 only from 2021 (Law of Ukraine “On Compulsory State Insurance") (Vidomosti Verkhovnoi Rady Ukrainy, 25.06.2020).

That is, Ukrainians acquire the right to receive a pension after reaching the age of 60 and having at least 27 years of insurance experience. Every next year, the number of insurance experience increases by 1 year and, starting from January 1, 2028, it must be at least 35 years. The minimum amount of pensions in Ukraine as of January 1, 2020 is 1,638 UAH (\$60.7), and by the end of 2020 it will increase by approximately to $8 \% 1,769 \mathrm{UAH}(\$ 65.5)$. The maximum 
pension in 2020 will increase from 15,640 UAH (\$579.2) to 16,380 UAH (\$606.6) (Pensiina reforma, 01.06.2020).

That is, the largest increase in the amount of pension will be for those who receive the maximum amount of pension.

Thus, the low level of pension implementation for Ukrainian pensioners, definitely, affects the material level of their lives. Most retirees are unable to buy the necessary food and to rest. Therefore, they do not meet the social needs for leisure and recreation. As a result, the measurement of life values is significantly reduced, limiting to the intention to meet the basic needs of life: food, medicine and clothing. Subsidies provided by the government to pay utility bills to families with extremely low pensions barely cover the costs of water, gas and electricity. Without doubt, the unsatisfactory material level affects the social and psychological well-being of Ukrainian pensioners, reducing their social immunity and trust in public authorities.

Meanwhile, it should be noted that not only Ukrainian but also European pensioners have their own problems that affect their moral and psychological state. The 2018 sociological study "Health status, mental health and air quality: evidence from pensioners in Europe" found that environmental quality is an important factor in determining people's well-being and therefore one of the main problems of governments is the improvement of air and public health. This is especially true for vulnerable demographic groups, such as the elderly (Giovanis, and Ozdamar, 2018).

In order for the pension system to work effectively in Ukraine, the state needs law protection for the average Ukrainian who is his client, state control over the guarantee of pension payments (state and non-state funds) to its members and effective work of all spheres of social production in Ukraine.

The challenges that exist in Ukraine hinder the improvement of the general social and economic situation. E. Libanova, Ukrainian academician, outlined three most important challenges, given the difficult social and economic situation in terms of quality of life: (1) inequality, which really exists; it is significant and it is felt by each Ukrainian; (2) a crisis of trust, because in our country "everyone does not trust everyone", except close relatives (among the positive dynamics has recently appeared a certain level of trust in compatriots); (3) total nihilism and unwillingness to work legally: "people want to work because they have to live somehow, but most try in various ways to hide their income from the government and at the same time do not shy away from demanding social protection and benefits" (Iakist zhyttia v Ukraini, 04.07.2020).

Under such conditions, it is important to maintain the moral and psychological state of elderly people, since sociological research by foreign researchres shows that the higher is the psychological well-being, the higer is the quality of life. When a person can lead his own life, he seems happy and finds the meaning in life. Therefore, social workers and government organizations working for elderly should raise public awareness of the activization of their 
personal lives, which in turn will help them to be happy and remain productive in society (Charles and Arockiam, 2020).

\section{Conclusions}

The problem of quality of life and improving its level is one of the main problems of our time in almost all countries of the world. There are many reasons that affect the condition and quality of life of people. These include political, economic, social, cultural, environmental and others. The low level of quality of life among the elderly people is particularly acute in those countries experiencing economic, political and environmental crises, including Ukraine.

However, in the scientific literature there is no ambiguous approach for understanding the category of "quality of life", so it is difficult to compare the phenomenon it describes in different countries. Therefore, in accordance with the purpose of this article, an analytical review of scientific approaches for understanding this category and clarifying its content was carried out. Also the state and quality of life of the population, including retirees in Ukraine, were analyzed.

It is emphasized that "quality of life" as a scientific category describes a multifaceted and quite difficult to study and evaluate social, economic, law, cultural and psychological phenomenon, which is inherent in each individual and community, society as a whole. As this category characterizes their living standards level implementation (economic, law, social, environmental, cultural, medical, psychological and others), their degree of satisfaction with the social and economic conditions created in the state to meet diverse (economic, educational, material, psychological, social, cultural, sports, leisure, etc.) needs and social support and protection by the government agencies and institutions in the event of loss of health or disability.

The main indicators for measuring the quality of life in Ukraine are the following: quantitative indicators of the external environment in which human life takes place and quality of life is assessed; characteristics of the current state of quality of life, which is formed as a result of the joint influence of the state and the population; subjective assessment of the quality of life of each individual (social strata, groups) in terms of their perception of the availability of different resources and the possibility of their use.

The analysis showed that almost majority of Ukrainians (up to 60\%) live below the poverty line, including the majority of pensioners. Extremely low pensions, delayed pension reform, and the lack of a guaranteed adequate level of pension insurance reduce the life chances of the elderly people. Therefore, maintaining their health and survival by engaging their own abilities and helping children remains virtually the only life value for them. Limited pension insurance, including the real absence of private pension funds, definitely, limits the ability of Ukrainian 
retirees to meet cultural needs, travel, buy healthy food, maintain communication with their friends.

Taking into account the experience of foreign countries such as Poland, Hungary, Estonia,Czech Republic in organizing national pension systems, it can be argued that private pension funds in all countries of the world are recognized as important social institutions. They contribute to the improvement of the financial situation of people of retirement age and have a high level of society members' trust in the pension savings system.

To guarantee a successful pension reform, Ukraine needs to act in three directions: create a competitive infrastructure (non-state pension funds, administrations, asset management companies), set adequate rates and protect the savings of depositors (Kuznecova, 2020).

In this regard, a promising area of further research on the problem considered in this work is the need to implement elements of the best standards of foreign pension systems, and develop the necessary measures to improve the second (mandatory funded system) and third levels (voluntary private pension provision) of the pension system. The third level of the pension system should guarantee the preservation and growth of accumulated pension benefits. This is possible under the condition of sustainable economic development of the country, the stock market of Ukraine, due to which non-state pension funds could increase the savings of pensioners or invest pension savings in other highly liquid assets. Public authorities must monitor this, because one of their top priorities is to ensure a decent standard of living for the elderly people, who have created tangible and intangible benefits for future generations.

\section{References}

1. Adamchuk, V.V. (1999). Ekonomika truda. Moskva: ZAO «Finstatinform».

2. Charles, S., Arockiam, K. (2020). Psychological well being and quality of life of Pensioners. ResearchGate. Available online https://www.researchgate.net/publication/ 339783826_PSYCHOLOGICAL_WELL_BEING_AND_QUALITY_OF_LIFE_OF_PE NSIONERS, 2021.01.12.

3. Chomu v Ukrä̈ni niz'kij riven' yakosti zhittya. Povidmlennya pres-sluzhbi. Nacional'na Akademiya nauk Ukraïni. Available online http:/www.nas.gov.ua/UA/Messages/Pages/ View.aspx?MessageID=5010, 2020.06.16.

4. Dani pro serednij rozmir pensiï stanom na 01.01.2020. Available online https://www.pfu.gov.ua/2119090-dani-pro-serednij-rozmir-pensiyi-stanom-na-01-012020/, 2020.06.26.

5. Deficit Pensionnogo fonda v 2014-2019 godah. Finansy. Available online https://ru.slovoidilo.ua/2019/09/26/infografika/finansy/deficit-pensionnogo-fonda-20142019-godax, 2020.06.26. 
6. Doslidzhennya tin'ovoï ekonomiki v Ukraïni: majzhe chvert' VVP - abo 846 mlrd griven' perebuvac $v$ tini, 17.02.2020. Available online https://bank.gov.ua/ua/news/all/ doslidjennya-tinovoyi-ekonomiki-v-ukrayini--mayje-chvert-vvp--abo-846-mlrd-griven-perebuvaye-v-tini, 2020.05.25.

7. Emerytura minimalna - wartości historyczne. Pox. P1. ZUS. Podatki. Finanse. Available online https://zus.pox.pl/zus/emerytura-minimalna-wartosci-historyczne.htm, 2021.01.13.

8. Giovanis, E., and Ozdamar, O. (2018). Health status, mental health and air quality: evidence from pensioners in Europe. Studies in Indian Place Names (UGC Care Journal), 86483. Available online https://mpra.ub.uni-muenchen.de/86483/1/MPRA_paper_86483.pdf, 2021.01.12.

9. Gukalova, I.V. (2009). YAkist' zhittya naselennya Ukraïni: suspil'no-geografichna konceptualizaciya. Kï̈v. Retrieved from https://igu.org.ua/sites/default/files/pdf-text/lifequality.pdf, 2020.06.22.

10. Ile wynosi średnia emerytura $w$ Polsce $w$ 2020? Zadlużenia.Com. Available online https://www.zadluzenia.com/srednia-emerytura-polska, aktualne notowania, https://www.fxmag.pl/artykul/kursy-walut-nbp-14-grudnia-2019-r-kurs-euro-funta-dolarai-franka-szwajcarskiego-w-sobote-aktualne-notowania, 2020.06.29.

11. Kolot, A.M. (2003). Social'no-trudovi vidnosini: teoriya i praktika: monografiya. Kiïv: KNEU.

12. Kurs NBU 1 yanvarya 2020. Available online https://minfin.com.ua/currency/nbu/2020-0101/, 2020.06.29.

13. Kurs valyut NBU na 1 yanvarya. Available online https://finance.i.ua/nbu/ $? \mathrm{~d}=1 \& \mathrm{~m}=1 \& \mathrm{y}=2021,2021.01 .13$.

14. Kursy walut. NBP. Available online https://www.nbp.pl/home.aspx?f=/kursy/arch_a.html, 2021.01.13.

15. Kuzior, A. (2006). Człowiek jako racjonalny podmiot działań w świetle założeń koncepcji zrównoważonego rozwoju. Problemy Ekorozwoju, vol. 1, $n r$ 2, pp. 67-72.

16. Kuzior, A. (2008). Paradygmat odpowiedzialności w perspektywie koncepcji sustainable developmen. Preszów. Preš : Filozoficka Fakulta Presovskej Univerzity, pp. 88-96.

17. Kuzior, A. (2011). Fizjologia głodu. In: A. Kuzior (Ed.), Globalne konteksty poszanowania praw i wolności czlowieka. Prawa człowieka w społecznej praktyce (pp. 43-53). Sosnowiec: Remar.

18. Kuzior, A. (2014). Aksjologia zrównoważonego rozwoju. Belianum: Banska Bystrzyca.

19. Kuznecova, Y.U. (10.12.2020). Luchshie pensionnye sistemy Evropy i krah v CHili: na chto vazhno smotret' Ukraine. Available online https://finance.liga.net/pension/article/luchshiepensionnye-sistemy-evropy-i-krah-v-chili-na-chto-vajno-smotret-ukraine, 12.01.2021.

20. Libanova, E.M., Gladun, O.M., Lisogor, L.S. et al. (2013). Vimiryuvannya yakosti zhittya v Ukraïni. Analitichna dopovid'. Kiïv: In-t demografiï ta social'nih doslidzhen' imeni M.V. Ptuhi NAN Ukraïni. Programa Rozvitku OON, MEPT Ukraïni. 
21. Minimimal'nyj $i$ maksimal'nyj razmer pensii po vozrastu $v$ 2021. Available online. https://www.profiwins.com.ua/ru/directories1/minpens.html, 2021.01.13.

22. Minimal'na pensiya za vikom. Pensia.ua Pensijnij konsul'tant. Available online https://pensia.ua/ua/baza-znan/statistichni-dani/item/914-minimalna-pensiia-po-viku, 2021.01.13.

23. Pensijna reforma Uryadu Grojsmana. Uryadovij portal. Available online https://www.kmu.gov.ua/gromadskosti/pensii, 2020.06.01.

24. Romanyuk, I. (2014). „Yakist' zhittya” yak social'no-ekonomichna kategoriya ta ob'ekt statistichnogo doslidzhennya. Ekonomika, No. 4(157), pp. 95-96.

25. Szyguła-Jurkiewicz, B., Kowalska, M., Mościński, M. Jakość życia jako element oceny stanu zdrowia $i$ efektywności leczenia chorych ze schorzeniami uktadu sercowonaczyniowego. Retrived from journals.viamedica.pl/folia_cardiologica/article/viewFile/ 23617/18803, 2020.06.15.

26. Vidomosti Verhovnoï Radi Ukraïni (VVR), 2003, No. 49-51, p. 376. Available online https://zakon.rada.gov.ua/laws/show/1058-15\#Text, 2020.06.25.

27. WHOQOL Group. The World Health Organisation quality of life assessment (WHOQOL): Position paper from the world health organisation (1995). Soc. Sci. Med., 41, 1403-1409.

28. Yacenko, V. (2018). Pensionnyj populizm: novye vyzovy i obeshchaniya. Reforme pensionnoj sistemy Ukrainy - dva desyatka let. V chem prichina neudovletvoritel'nyh rezul'tatov? Ekonomichna Pravda, 18.09.2018. Available online https://www.epravda.com.ua/rus/columns/2018/09/18/640675/, 2020.06.29.

29. Yakist' zhittya v Ukraïni: ocinki ekspertiv. Uryadovij kur'er, 04.07.2020. Available online https://ukurier.gov.ua/uk/articles/yakist-zhittya-v-ukrayini-ocinki-ekspertiv/, 2020.06.29. 